\title{
McArdle Laboratory for Cancer Research
}

National Cancer Institute

\section{Source}

National Cancer Institute. McArdle Laboratory for Cancer Research. NCI Thesaurus.

Code C39455.

The McArdle Laboratory for Cancer Research, the Department of Oncology of the University of Wisconsin-Madison, is an $\mathrm{NCl}$-designated Cancer Center. The McArdle Laboratory has 21 independent research laboratories organized into following programs: Tumor Virology, Signal Transduction, Cell Cycle, Cancer Genetics, Chemical Carcinogenesis. The Laboratory has 13 shared facilities. 